\title{
K 2016
}

秋 元 英 郎*

\section{1.はじめに}

2016 年 10 月 19 26 日にかけてドイッデュッセルドル フのメッセ会場にて世界最大のゴム・プラスチック展 K 2016 が開催された. 3 年に一度開催される本展示会には, 私自身 2004 年から連続して視察しており, 今回が 5 回目 となる．会期が 8 日間と長いこともあるが，来場者数は 23 万人, 出展者数 3285 と世界最大に偽り無い.

本報告では, 射出成形と材料に関係する展示の中で特に 目についたものをピックアップして報告する.

\section{2. 炭素繊維/ガラス繊維強化シートの複合成形}

長瀻維を熱可塑性樹脂と複合化したシートを予熱した後 に金型にインサートしてインサート成形を行う工法であ り，2010 年から見られるようになった。 今回も ENGEL と KraussMaffei が成形実演を行っていた。 また，シート の供給元である LANXESS のブースにはこの工法による 本田の燃料電池車に採用されたバンパービームも展示され ていた.

一方，この工法と組合せで提案されてきたガラス繊維を ロービングから射出成形機のバレルに導入する成形は見ら れなかった。

\section{3. 発泡成形}

ENGEL は後述する加飾成形において MuCell（微細発 泡成形）を実演していた。

Wittmann Battenfeld は独自に開発した物理発泡技術 CELL MOULDの成形実演を行っていた。この工法は空 気中の窒素を分離して超臨界状態まで圧縮して成形機のバ レルから注入する方法である. 基本的なところは MuCell と変わらないが, 専用のスクリューを展示し, MuCell と の違いも説明していた.

ARBURG は IKV が開発した新規の物理発泡プロセスの 成形実演を行っていた。このプロセスの特徵は $3 \sim 5 \mathrm{MPa}$ に加圧した窒素ガスをホッパーからバレル内に導入する方 式になっている点である。 そのためホッパーは上下の $2 つ$

\footnotetext{
Akimoto, Hideo

秋元技術士事務所

千葉市美浜区中瀬 1-3 幕張テクノガーデン $\mathrm{CB}$ 棟 $3 \mathrm{~F} \quad \mathrm{MBP}$ 内 ( т 261-0023)

Hideo.Akimoto@ce-akimoto.com

2016.12.4 受理
}

のゾーンに区切られて，それぞれで窒素ガスの圧力が制御 され，材料の供給時にガス圧が下がらないように制御され いる．供給されたガスは可塑化された材料の表面から溶解 し，溶解量はガス圧によって制御されている模様である. 研究機関である fraunhoferのブースではエラストマー と PPの 2 色成形において PP をコアバックで膨らませた サンプルが展示されていた。しかしながらヨーロッパでは 日本ほどはコアバックに関する開発が盛んではないようだ.

\section{4. 加 飾 成 形}

ENGEL はエラストマーのシートを予熱して可動型の キャビティで真空賦形した後に型閉じして樹脂を射出する 成形を実演していた。金型加熱泠却（ヒート\&クール）の 効果もあって成形品表面のシボや縫い目模様も非常にきれ いに転写されていた。

ENGEL はまた，前述の長繊維強化シートの成形と同時 に金型内転写を行っていた.

KraussMaffei は対向 2 色成形機を用いた金型内塗装を 実演していた．固定側で樹脂を射出し，可動側で塗料を注 入する方法である. 塗料は 2 液のポリウレアであり, 混合 されて金型近傍まで移送されたのちに色材が添加混合され る. 色材の添加位置を金型近くにすることで色替え時間が 5分ほどに短縮されるとともに, 装置の磨耗の原因となって いたメタリック塗料も使えるようになったとのことである。

Sumitomo SHI Demag は金型内転写とそれに続く紫外 線硬化処理の実演を行っていた。加飾用の転写フィルムに 抒いて転写後に最表面に出る層に紫外線硬化型のハード コート剤を配置することで，転写後に紫外線照射炉に移動 させて硬化処理を行っていた．同社は前回の K 2013 では 透明樹脂の表面に紫外線硬化型のハードコート剤の転写と 董面に電子回路を印刷した透明フィルムの貼り合せを同時 に行う実演を行っており，その流れである。

$$
\text { 5. インジェクションブロー成形 }
$$

通常の射出成形機を用いて金型動作の工夫によってイン ジェクションブロー成形を行う試みが見られた. Wittmann Battenfeld の実演では可動型が回転する形になっており， プリフォームを射出した後に可動プラテンが回転してブ ロー用キャビティに移動して膨らませる工程であった. BOY の実演では金型内の入れ子のみが回転する方式で あった。 
一方で ENGEL は固定型，中間回転型，可動型のセット からなる Cube Mold を用いてブロー成形を行っていた. Cube Mold は垂直に回転軸を持つ中間回転型を回転させ るわけであるが，キャビティが 4 面に彫られてあり，操作 側や反操作側での作業が可能である. ENGEL のプロセス では固定側でプリフォームを射出, 操作側で加熱, 可動側 でブロー, 反操作側で取出しという流れになる.Cube Mold を使うことでサイクルタイムが短縮可能になっている.

\section{6. $\mathrm{R}$ T $\mathrm{M}$}

RTM（レジン・トランスファー・モールディング） と はガラス繊維や炭素繊維のマットが挿入された金型内に樹 脂を流す工法であるが，熱可塑性樹脂は粘度が高いために 纎維の隙間に充分に含浸しないためエポキシ樹脂等の熱硬 化性樹脂が使われることが多い.

一方，今回は熱可塑性を謳う RTM の実演が行われてい た. 実際には熱可塑性樹脂を流すのではなく, カプロラク 夕ムを金型内に流し込んだ後に金型内重合する方法である. 重合時間は3〜4分でもう少し短縮してほしいところである。

KraussMaffei は炭素繊維とガラス繊維の複合マットを インサートしてカプロラクタムを注入する工程を実演して いた．カプロラクタムは熱安定性に乏しいため，必要な分 だけ $120^{\circ} \mathrm{C}$ に昇温して融解し， $180^{\circ} \mathrm{C}$ の金型内で重合して いた.

ENGEL はガラス繊維のマットを金型内にインサートし てカプロラクタムを重合した後に別のキャビティに移して ガラス強化 PA 6 を射出する変則的な 2 色成形を実演して いた.

カプロラクタムを重合して熱可塑性樹脂にするメリット は熱硬化性樹脂に比べて耐衝撃性に優れる点と後工程にお ける溶着が可能になる点にある. 今後は未反応物を最小限 に抑えながら反応時間の短縮が進められる計画とのことで ある・

\section{7. ヒート\&クール成形}

前回まではピアノブラックの成形実演が多かったが，今 回はピアノブラックは姿を消し, シボ転写性の実演が多く 見られた.

KraussMaffei は Roc Tool の電磁誘導加熱を用いたヒー ト\&クール成形により三次元形状の成形品の表面シボ転写 を実演していた．意匠面のキャビティ面から等距離の位置 にインダクタを配置することで三次元形状に沿って加熱が 可能になっている.

RocTool は自社のブースにおいて Krauss Maffei の成形 機を用いてデザイン性の高い微細なシボの転写を成形実演 していた. 特にホログラムのような微細なパターン転写を 実際の射出成形のプロセスで見せていた。

gwk は加熱冷却配管を三次元形状に配置した金型を用 いてヒート\&クール成形を実演し, 高シボ転写特性を見せ ていた.

\section{8. 液状シリコーンの射出成形}

液状シリコーン（特に 2 液型）を用いた射出成形も多く 見られたが，熱可塑性樹脂との組合せとしてはPBT との
組合せが定番となっており, ENGEL, Wittmann Battenfeld が成形実演していた。

ARBURG は熱可塑性樹脂との二色成形ではなく, 硬度 の異なる液状シリコーン同士の二色成形を実演していた。 この成形は最後に腕時計に仕上げて配っていたため，1時 間待ちの長蛇の列になっていた.

\section{Additive Manufacturing（3 D プリンター)}

前回華々しくデビューした ARBURG の 3 D プリンター freeformer は今回もブースの中心に置かれていた，射出 成形用のペレットをそのまま投入して造形できる点が一番 の特長であるが, 強度面でも射出成形の 8 割程度の強度が 出るようになっている. いろいろなアプリケーションが可 能になってくるであろう。

Covestroのブースではウレタン系材料の $3 \mathrm{D}$ プリン ターへの応用に関する展示があった. 同社は $3 \mathrm{D}$ プリン ター用途に注力している．特にスポーツシューズのミッド ソールおよびアッパーを $3 \mathrm{D}$ プリンターで造形したサンプ ル展示が目についた。

\section{0. 材料メーカーの展示}

材料メーカーの展示方法には大きく分けて 3 種類ある. ひとつは製品紹介パネルとサンプルを並べる方法，比較的 多いのがスペースの大部分を商談スペースにしている方法 であらかじめアポイントをとった人を対象に打合せを行う というもの, そして前回から目立ち始めたのがソリュー ション型のブースである. 特に BASF, Covestro はその代 表である.

BASF は次世代自動車を現代自動車と共同で開発して展 示していた。これは，材料のみならずデザインや安全設計 まで踏み込んでの共同開発である。軽量化の提案としては ボディ外板の素材をウレタン RIM にし，内装材は天然緎 維を水性アクリルのバインダーで結合させたものを使って いた。

BASF は他にも素材にPA を使った電動の 1 人乗り用移 動手段を提案していた。これも材料の提案というより都市 における新しいライフスタイルの提案である.

Covestro は自動車のボディをオール PC（ポリカーボ ネート）化したコンセプトカーを展示していた.フロント グリルがディスプレイになり, リアコンビネーションラン プはマイクロレンズになっていて厚み $2 \mathrm{~mm}$ にも関わらず 厚みがあると錯覚させている．ホイールカバーも $\mathrm{PC}$ 製で 開閉する構造になっており，走行中は空気抵抗を下げるた めに閉じ，停車中やブレーキ作動中は放熱のために開くと いうものである.

BASF, Covestro ともにあえて炭素繊維複合材料を用い ずに今ある材料を活用している。自動車が電気自動車にシ フトすることでエンジンルーム内の熱対策が不要なるとい う状況が背景にある。

\section{1.おわりに}

$\mathrm{K}$ ショウ開催期間中はデュッセルドルフ市内のホテルは 通常の 5 倍以上の価格になり, 周辺のエッセン，ケルン， ボン等に泊る人も多い。それだけ，見る価值がある展示会 
である。

とかく動きがある射出成形機メーカーの成形実演にばか り目が行きがちであるが，材料メーカーの展示コンセプト の変化によって全体的に良く見ないと何が言いたいかわか らないが,良く見ると非常に奥が深い展示が増えてきている.

本記事は紙面の制約から写真を載せることができなかっ
た. 参考サイトには写真を掲載しているので興味がある方 は見て欲しい。

\section{2. 参考サイト}

K 2016 レポート（射出成形機, 成形材料, 特殊成形) http : //plastics-japan.com/archives/1817

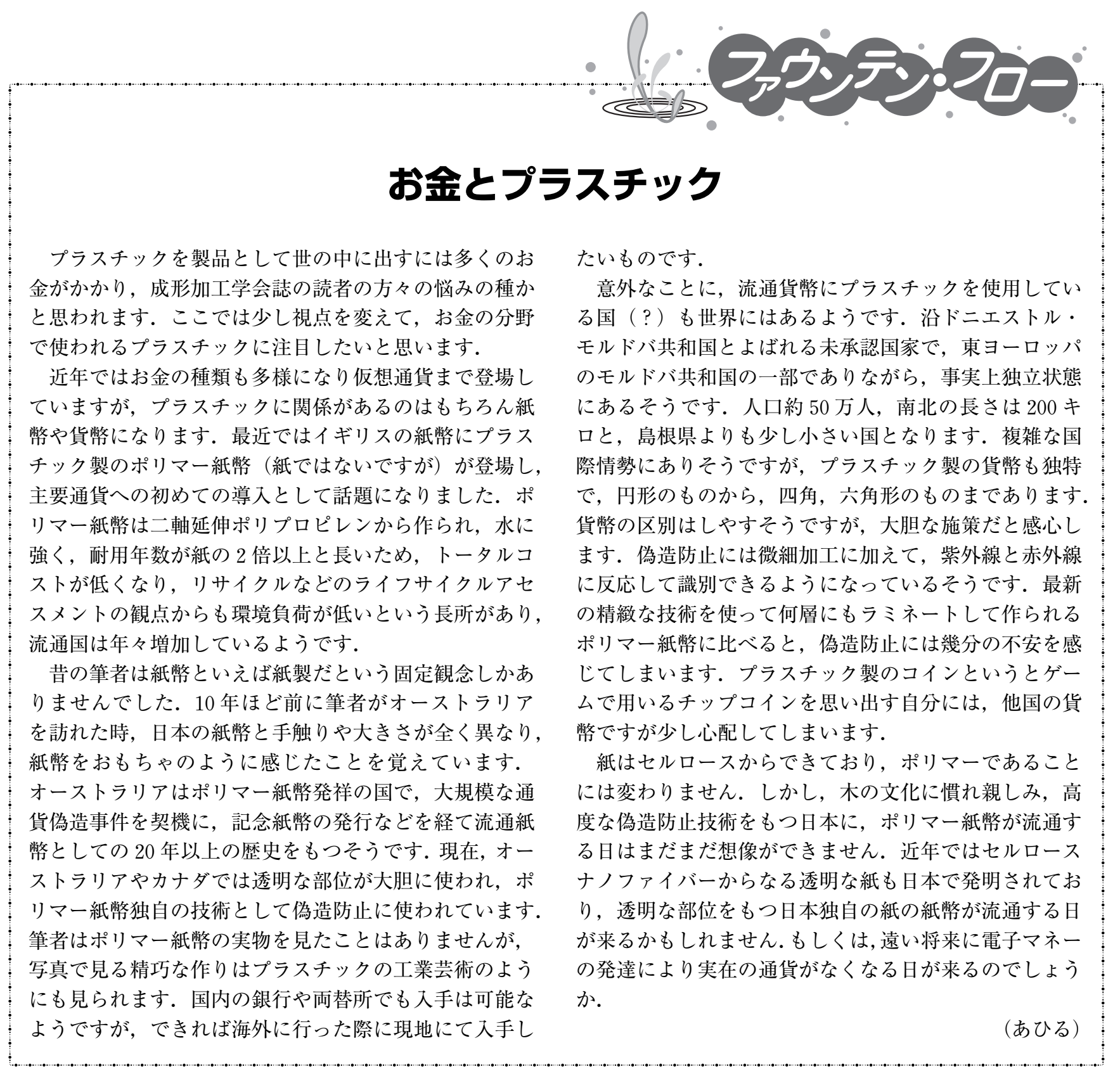

